NBER WORKING PAPER SERIES

\title{
DO ENTRY REGULATIONS DETER ENTREPRENEURSHIP AND JOB CREATION? EVIDENCE FROM RECENT REFORMS IN PORTUGAL
}

\author{
Lee G. Branstetter \\ Francisco Lima \\ Lowell J. Taylor \\ Ana Venâncio \\ Working Paper 16473 \\ http://www.nber.org/papers/w16473 \\ NATIONAL BUREAU OF ECONOMIC RESEARCH \\ 1050 Massachusetts Avenue \\ Cambridge, MA 02138 \\ October 2010
}

The authors thank the Portuguese Ministry of Justice, and particularly the Institute of Registration and Notarization (Instituto dos Registos e do Notariado), for data on one-shop stops. We thank Maria do Céu, Gabriela Isidro and Ana Sommer for research assistance. We are also indebted to the Portuguese Ministry of Employment and Social Security and Gabinete de Estratégia e Planeamento (GEP) for giving us access to the matched employer-employee data. Financial support was provided by the Fundação para a Ciência e a Tecnologia (Portuguese Foundation for Science and Technology) through the Carnegie Mellon Portugal Program under Grant SFRH/BD/39666/2007, and project PTDC/ESC/71080/2006. All errors remain our own. Views expressed are those of the authors and do not necessarily reflect those of the National Bureau of Economic Research or any branch or agency of the Government of Portugal.

NBER working papers are circulated for discussion and comment purposes. They have not been peerreviewed or been subject to the review by the NBER Board of Directors that accompanies official NBER publications.

(C) 2010 by Lee G. Branstetter, Francisco Lima, Lowell J. Taylor, and Ana Venâncio. All rights reserved. Short sections of text, not to exceed two paragraphs, may be quoted without explicit permission provided that full credit, including $(\odot)$ notice, is given to the source. 
Do Entry Regulations Deter Entrepreneurship and Job Creation? Evidence from Recent Reforms in Portugal

Lee G. Branstetter, Francisco Lima, Lowell J. Taylor, and Ana Venâncio

NBER Working Paper No. 16473

October 2010

JEL No. D73,K22,L26,L53

\begin{abstract}
Recent research has suggested that the reduction of entry regulation can promote firm entry and job creation, but little is known about the quality of firms and jobs created through these reforms. To shed light on this question, we employ data from Portugal, a country which implemented one of the most dramatic and thorough policies of entry deregulation in the industrialized world. The impact of these major changes can be traced with a matched employer-employee database that provides unusually rich information on the quality of founders and employees associated with the new firms. Our assessment indicates that the short term consequences of the reform were just as one would predict with a standard economic model of entrepreneurship: The reform resulted in increased firm formation and employment, but mostly among "marginal firms" that would have been most readily deterred by existing heavy entry regulations. These marginal firms were typically small, owned by relatively poorly-educated entrepreneurs, operating in the low-tech sector (agriculture, construction, and retail trade). These firms were also less likely to survive their first two years than comparable firms that entered prior to the reform. The social impact of entry deregulation may be limited by the quality of the firms it creates.
\end{abstract}

Lee G. Branstetter

Heinz College

and

Department of Social and Decision Sciences

Carnegie Mellon University

Pittsburgh, PA 15213-3890

and NBER

branstet@andrew.cmu.edu

Francisco Lima

Department of Engineering and Management

Instituto Superior Técnico and CEG-IST

Technical University of Lisbon

Av. Rovisco Pais

1049-001 Lisboa Portugal

francisco.lima@hist.utl.pt
Lowell J. Taylor

H. John Heinz III Professor of Economics

Heinz College

Carnegie Mellon University

5000 Forbes Avenue

Pittsburgh, PA 15213-3890

and NORC

1t20@andrew.cmu.edu

Ana Venâncio

Management Department

ISEG - Economic and Business School

Technical University of Lisbon

R. Miguel Lúpi, 20

1200-781 Lisboa Portugal

avenancio@iseg.utl.pt 


\section{Introduction}

Do burdensome entry requirements hamper the creation of new firms and stand in the way of economic growth? There are solid theoretical reasons to believe that governmentimposed fixed costs to firm formation deter entrepreneurship and reduce labor demand. Two important strands of empirical work suggest that existing barriers have economically important effects in practice.

One set of analyses is based on cross-country comparisons. These papers compare countries in terms of the stringency of entry regulation, and ask if that variation is correlated with measures of economic performance. For instance, in an influential paper, Djankov, La Porta, Lopez-De-Silanes and Shleifer (2002) establish that the official costs of business entry are extremely high in many countries, and they show that onerous entry regulation is associated with higher corruption and a higher concentration of activity in the informal sector. They find no evidence to suggest that high entry costs create value through improved quality of either publicly or privately provided goods. Many subsequent papers have used similar empirical strategies to evaluate the impact of the regulation of business entry, suggesting that such regulation is associated with reduced job creation (Ciccone and Papaioannou, 2007), higher industry concentration (Fisman and Sarria-Allende, 2004; Klapper et al., 2006), and reduced entry of new firms (Klapper et al., 2006; Dreher and Gassebner, 2007; Ciccone and Papaioannou, 2007; Bjørnskov and Foss, 2008) ${ }^{1}$.

Of course, empirical work that relies on cross-national correlations leaves researchers with a difficult inference problem - an issue that receives an extended and insightful discussion in the original work of Djankov et al. (2002). While it is important to know that heavy entry regulation is associated with poor economic performance within countries, that correlation alone is not sufficient to assess the likely consequence of regulation reform in practice. After all, as Djankov et al. (2002) demonstrate, countries with heavy entry regulation also are less likely to have "good government" along a number of dimensions. One might be concerned, for instance, that entry regulation reform, on its own, would have limited success in a country with other deep structural economic and political problems.

As an alternative to cross-country analyses, a second complementary literature seeks to directly assess the consequences of policies that reduce firm entry costs using time-, regionand/or industry-specific variation in entry costs created by policy changes within particular countries. Bertrand and Kramarz (2002), for example, carefully evaluate entry barriers in France's retail industry. That paper presents evidence that stronger entry deterrence increased industry concentration and reduced employment growth. A second prominent example is the work by Aghion et al. (2008), which shows that the dismantling of the License Raj in India (a system of central controls that regulated entry and output expansion) resulted in industry growth, but did so in ways that were tied to other features of the states in which

\footnotetext{
${ }^{1}$ More generally, to date nearly 200 academic articles have utilized either the original Djankov et al. (2002) data set or updated versions published by the World Bank, as part of the World Bank's Doing Business Project, which tracks regulatory reforms in 181 countries. The World Bank indicators are widely used. For example, the Millennium Challenge Corporation, set up by the United States to channel aid to developing countries, uses these and similar indicators to screen applicants for U.S. development aid. Djankov (2009) provides more examples and details.
} 
the reforms were occurring. ${ }^{2}$

Our paper contributes to this second stream of research by evaluating the impact of entry deregulation in Portugal. Prior to 2005 the barriers facing entrepreneurs in Portugal were among the highest in Western Europe, according to World Bank measures. In 2005 Portugal implemented the "On the Spot Firm" program (Empresa na Hora) which established "onestop shops" that offered prospective entrepreneurs significantly reduced administrative fees, and simplified incorporation procedures. The reform reduced the time delay of legal incorporation from several months to as little as one hour, and also reduced monetary fees that initially were on the order of 2000 Euro to less than 400 Euro. Over the next several years, these offices were opened across the country. As a consequence of this reform, Portugal's ranking in the World Bank's "Doing Business Index" moved from 113rd out of 155 countries to 33rd, and Portugal was cited by the World Bank as the top reformer in business entry regulation in $2005 / 2006$. Portugal thus provides an excellent context in which to evaluate the impact of substantial entry regulation reform. What effect did this reform have on firm and job creation? What types of entrepreneurs benefited from this reform? How well did any new "marginal" firm entrants perform over time?

To answer our key questions, we use micro-level data and examine the implementation of the Portuguese business registration reform in different counties at different time periods. Our data provide detailed information on the new firms established in each county between 2000 and 2008. For each firm, we were able to gather information on size, founder characteristics, and firm survival. The fact that adoption of the reform varied across county and time is helpful for our identification strategy. The richness of our data allows us to compare the characteristics of new firms created by the reform to those that emerged prior to its implementation, providing a dimension of analysis that has been missing in the previous literature.

We find that in the short run, the Portuguese reform increased the number of business start-ups by approximately 17 percent, and created approximately seven new jobs per 100,000 county inhabitants per month in eligible industries. There is evidence to suggest that the "marginal firms"- firms that entered as a consequence of reduced entry costs - were operated by proprietors who were disproportionately older, more female, and less educated than proprietors of infra-marginal firms. The marginal firms were typically low-tech, e.g., in the agricultural, retail trade, and construction industries. We also find that start-ups established after the program are smaller and less likely to survive in the first two years than firms founded in the absence of the program. Taken together, these results suggest that entry deregulation has had a modest positive impact on firm and job creation in Portugal. The barriers that existed prior to deregulation were a significant impediment for some entrepreneurs, but less of an impediment to the larger, high-quality firms that are most likely to create substantial economic growth. These lessons are likely to extend beyond the Portuguese context of this study, and suggest that the ultimate impact of business entry deregulation may fall somewhat short of current expectations.

\footnotetext{
${ }^{2}$ See also Chari (2007) on the License Raj. Other relevant examples include analyses of Russian reform (Yakovlev and Zhuravskaya, 2007) and entry regulation reform in Mexico (Kaplan et al., 2009; Bruhn, 2008) and Brazil (Monteiro and Assunção, 2006).
} 
The remainder of this paper is structured as follows. In section 2, we provide a brief overview of the literature on entry regulation. Section 3 develops a simple model for the purpose of highlighting expected the effects of entry deregulation on entrepreneurial outcomes. Section 4 describes the Portuguese business simplification reform in further detail. A description of the data follows in section 5. In section 6, we present the empirical strategy, results and robustness checks. Section 7 concludes.

\section{Entry Regulation: Theory and Existing Evidence}

Two contrasting theoretical views of entry regulation have long been debated: "public choice" and "public interest" theories. The first regards regulation as socially inefficient, and as a mechanism to create and extract rents. This view holds that regulation either benefits bureaucrats and politicians by collecting bribes from entrants (De Soto, 1989) or benefits incumbent firms by deterring the competition of potential entrants (Posner, 1975; Peltzman, 1976; Stigler, 1971). In contrast, public interest theory provides a potential rationale for entry barriers: regulation might help correct market failures and achieve socially superior outcomes (Pigou, 1938), for example, screen new firms, thereby reducing low-quality products or damaging externalities.

Recent empirical evidence does not appear to square with public interest theory. Many papers, some of which we have cited above, suggest that entry regulation indeed has the expected first-order effect of reducing firm entry and affecting the market structure. ${ }^{3}$ Djankov (2008), among others, argue that the main beneficiaries of complex entry regulation are often incumbent firms, which see their rents and competitive position protected by burdensome entry requirements. Considerable effort has also been devoted to studying the link between regulation and macro-economic outcomes such as employment, productivity and growth (Bertrand and Kramarz, 2002; Alesina et al., 2005; Djankov et al., 2006; Yakovlev and Zhuravskaya, 2007; Chari, 2007; Kaplan et al., 2009; Aghion et al., 2008; Barseghyan, 2008; Bruhn, 2008). Stricter regulation is linked to slower growth, lessened productivity, inhibited investment and decreased employment (particularly in high-skilled jobs, according to Barseghyan (2008)). Some evidence suggests that entry regulation induces business to operate in the informal sector (Djankov et al., 2002; Monteiro and Assunção, 2006).

In an effort to take seriously the concerns raised by public interest theory, some work focuses on the impact of regulation on market failures such as sub-standard product quality, pollution or public health (Djankov et al., 2002; Yakovlev and Zhuravskaya, 2007; Bruhn, 2008). Most work along these lines finds no evidence of beneficial effects of entry regulation.

As we have mentioned, much of the existing work relies on cross-national variation. Causal inference here is difficult. For example, governments might regulate more heavily in countries where there are more market failures, or regulators might focus effort on rent extraction in countries where such extraction is made possible by other structural deficits in governance. Omitted variables can jointly drive economic outcomes and regulation. One

\footnotetext{
${ }^{3}$ See, e.g., Djankov et al. (2002); Bertrand and Kramarz (2002); Fisman and Sarria-Allende (2004); Klapper et al. (2006); Ciccone and Papaioannou (2007).
} 
potential path is to search for instruments that drive regulation decisions, ${ }^{4}$ or to draw lessons from such specific quasi-experiments as German reunification (Prantl and Spitz-Oener, 2009) or reform in Russia (Yakovlev and Zhuravskaya, 2007).

While useful, these approaches are not a substitute for empirical evaluations of actual policy shifts that change entry regulation. There are two reasons why our examination of the Portuguese policy shift holds particular promise. First, the policy shift was quite simple and, as we discuss below, dramatic. Second, we have access to extraordinary panel data on firms, their employees, and their founders. Thus, in comparison to the extant literature, we are able to evaluate the impact on firm entry and job growth, and also the kinds of start-ups and entrepreneurs that appeared to benefit from deregulation. Previous empirical work has suggested that entry regulation results in increased firm size (Desai et al., 2003; Fisman and Sarria-Allende, 2004; Klapper et al., 2006). Beyond that, little is known about the nature and quality of the firms that can be expected to enter when governments adopt deregulation. This is a significant gap in the literature because the social impact of deregulation will be a function not only of the number of new firms brought into the market, but also their quality, size, performance, and longevity.

\section{A Simple Model}

To fix ideas, and set the stage for the empirical analysis that follows, we develop a simple model here that draws on the logic given in the seminal work of Lucas (1978).

We evaluate an economy in which agents can choose between three options in each period: (i) home production (or leisure), which provides monetized utility $w$, (ii) supplying one unit work in a competitive labor market, or (iii) becoming an entrepreneur and hiring other agents. In equilibrium, agents are indifferent between the first two possibilities, and we assume that there are some agents in each of the two possible categories. So to induce agents to supply labor, the labor market must pay wage $w .^{5}$ Agents pursue entrepreneurship when the expected rewards equal or exceed $w$.

We assume, as does Lucas (1978), that our economy is populated by individuals who have identical abilities as workers, but who are endowed with different levels of entrepreneurial ability, $\theta$, drawn from a continuous probability distribution $g(\theta)$, with support $\left[\theta_{l}, \theta_{u}\right]$. Entrepreneurial ability is a unique scarce resource (as in Schumpeter (1934)), which allows individuals to create and manage firms effectively.

To make matters interesting, we introduce a dynamic element by allowing agents to live for two periods. In the first period, an agent with endowment $\theta$ can choose home production

\footnotetext{
${ }^{4}$ For example, a country's legal and political origin is often treated as an instrument in this literature (Fisman and Sarria-Allende, 2004; Djankov et al., 2006; Dulleck et al., 2006; Barseghyan, 2008).

${ }^{5}$ Our assumptions imply that labor supply is perfectly elastic. This is a particularly transparent case for analysis. We might alternatively have chosen to analyze the equally transparent case of perfectly inelastic labor supply, as does Lucas (1978) However, that case rules out (by assumption) an interesting question we want to examine: Does entry regulation affect equilibrium employment? The intermediate case, with upward-sloping supply, adds considerable complication with no additional insight, so we do not pursue it here.
} 
or work, in which case the payoff is $w$. Alternatively, she can become an entrepreneur, and receive a payoff $\pi_{1}(\theta)$ that is a known function of her entrepreneurial ability plus a meanzero term, say $\epsilon$ (drawn from a known distribution), that reflects uncertainty that cannot be resolved until a potential entrepreneur actually opens her firm. To keep analysis simple, we let the value created by a firm take a constant-returns-to-scale Cobb-Douglas form in entrepreneurial ability and labor employed. ${ }^{6}$ The first-period payoff is

$$
\pi_{1}(\theta)=\theta^{\frac{1}{2}} L^{\frac{1}{2}}-(w L+F)+\epsilon
$$

where $L$ is the quantity of labor employed, and $F$ is a fixed cost to opening the firm. In the second period, the agent retains her (now revealed) idiosyncratic term $\epsilon$ but faces no additional fixed cost. So

$$
\pi_{2}(\theta)=\theta^{\frac{1}{2}} L^{\frac{1}{2}}-w L+\epsilon,
$$

if she continues to operate. If, instead, our entrepreneur closes her firm (as she might if she has a particularly poor $\epsilon$ draw), she earns $w$.

Given this set up, it is easy to verify that an optimizing entrepreneur with ability $\theta$ and idiosyncratic draw $\epsilon$ earns

$$
\pi_{1}(\theta, \epsilon)=\frac{\theta}{4 w}-F+\epsilon
$$

and

$$
\pi_{2}(\theta, \epsilon)=\left\{\begin{array}{lll}
\frac{\theta}{4 w}+\epsilon & \text { if } \quad \epsilon \geq w-\frac{\theta}{4 w}, & \text { and } \\
w & \text { if } \quad \epsilon \leq w-\frac{\theta}{4 w} .
\end{array}\right.
$$

Clearly, the value of operating as an entrepreneur depends on one's ability $\theta$, relative to the market wage $w$. Importantly for our purposes, the value of entrepreneurship depends also on the level of the fixed cost $F$, and so too, therefore, does the decision to become an entrepreneur. To illustrate, let $\epsilon$ be drawn from a uniform distribution with support $\left[-\epsilon_{u}, \epsilon_{u}\right]$. Then with a bit of algebra it is easy to confirm that a risk-neutral agent will choose to open a firm if, and only if

$$
\left[\frac{\theta}{4 w}-w\right]+\frac{1}{4 \epsilon_{u}}\left[\left(\frac{\theta}{4 w}-w\right)+\epsilon_{u}\right]^{2} \geq F
$$

(assuming a zero rate of time discounting). Expression (5) makes sense. The first bracketed term on the left-hand side is expected pure profit from operating in the first period. In a one-period model, the entrepreneurship decision would hinge solely on whether this term was as large as the fixed entry cost. There is an option value, though, associated with continued operation in the second period, and this is represented by the second, strictly positive, term on the left-hand side of (5).

Let $\hat{\theta}$ be the value of $\theta$ that solves (5) with equality. Then the fraction of agents who become entrepreneurs is $1-G(\hat{\theta})$, where $G()$ is the c.d.f. for $g($ ). Inspection of (5) gives the intuitive result that $\hat{\theta}$ is strictly increasing in $F$; the lower the entry cost, the lower is the threshold that induces agents to open firms. In turn, the lower the entry cost, the higher will be the fraction of agents who become entrepreneurs.

\footnotetext{
${ }^{6}$ As part of our effort to keep things clear, we have no capital here.
} 
Labor market employment in our economy of course depends on the level of entrepreneurship. In particular, an entrepreneur with ability $\theta$ employs $\theta / 4 w^{2}$ workers in period 1 , and employs that same number in period 2 if she continues operation. So in our economy, a decrease in $F$ increases employment (while decreasing the number of agents in home production). Notice that the firms that form as a consequence of a reduction in $F$ will be operated by proprietors with relatively low levels of $\theta$, and these firms will tend to be small, since labor demand is proportional here to entrepreneurial ability $\theta$.

Finally, we note that the probability of firm survival in period 2 is also related to $\theta$. In particular, a bit of algebra can be used to confirm that a firm's survival probability is

$$
s(\theta)=\frac{\theta}{8 w \epsilon_{u}}+\frac{1}{2}-\frac{w}{2 \epsilon_{u}} .
$$

Firms with high-ability proprietors (which are also firms with relatively more employees here) have a higher survival rate. Given that the distribution of talent among operating firms is $g(\theta) /[1-G(\hat{\theta})]$, average firm survival is

$$
\bar{s}=\int_{\hat{\theta}}^{\theta_{u}}\left[\frac{\theta}{8 w \epsilon_{u}}+\frac{1}{2}-\frac{w}{2 \epsilon_{u}}\right] \frac{g(\theta)}{1-G(\hat{\theta})} d \theta,
$$

which can be written

$$
\bar{s}=\frac{1}{8 w \epsilon_{u}} E(\theta \mid \theta \geq \hat{\theta})+\frac{1}{2}-\frac{w}{2 \epsilon_{u}} .
$$

A reduction in $F$ results in a reduction in the cut-off $\hat{\theta}$, and this in turn reduces the mean ability level of entrepreneurs. The consequence is to reduce average firm survival.

To summarize, our model provides an intuitive set of predictions about the consequence of a reduction in the cost of firm entry, i.e., a reform of the sort enacted in Portugal:

1. Increased business formation: A higher proportion of agents become entrepreneurs.

2. Increased employment: A higher proportion of agents are employed; fewer are in home production.

3. All shifts occur at the margin: New firms will generally have entrepreneurs with relatively lower talent. These firms will generally be smaller, and will have lower survival probabilities than infra-marginal firms.

It is worth noting that our model has some predictions that differ in the short- and long-run. For example, in our set-up only young agents form firms, because only they can take advantage of the option value of continued operation in case the firm proves to be particularly successful. ${ }^{7}$ A short-run consequence of reduced entry cost would be to cause some older entrepreneurs to form new firms. These would be agents who were deterred by high entry costs when they were young, but now find entrepreneurship to be more attractive. So in the short run, the average age of new entrepreneurs rises. In the long run, though,

\footnotetext{
${ }^{7}$ In a more complete model, the relationship between age and entrepreneurship becomes more complicated. Experience can increase ability, but agents still face the need to recoup the fixed costs of starting a firm over a sustained period of operation, making entrepreneurship less attractive for older workers.
} 
once again only young agents form firms.

Finally, we note that in our model artificial barriers that increase entry costs introduce inefficiency; these regulations induce some potential entrepreneurs to unnecessarily and inefficiently decide to work for others or remain out of the labor force. Empirical support of the model's key predictions thus constitutes some useful prima facia evidence in favor of the proposition that reduced entry regulation is socially useful. If, to the contrary, one were to show little impact of entry deregulation, there would be less reason to be concerned about entry regulation as a practical concern. Conceivably, one might even find that reduced entry regulation reduces employment if markets are non-competitive. ${ }^{8}$

\section{The "On the Spot Firm" Program}

In this section, we describe the Portuguese business registration reform and the setting in which it was implemented.

Prior to 2005, to meet the government requirements, an entrepreneur had to visit several different public agencies, complete 11 procedures, fill out 20 forms and documents, wait between 54 and 78 days and pay almost 2,000 Euro (approximately 13.5 percent of per capita gross national income). These numbers were high by international standards, making Portugal one of the least attractive countries in which to start a business. ${ }^{9}$ Pressure to reform this system increased as the country's economic performance deteriorated after 2000. Between 1996 and 2000, the economy had experienced a period of reasonably good growth (real GDP increased by approximately 4.0 percent annually), but from 2001 to 2005 growth fell to less than 1.0 percent.

In response to the poor administrative record, and weak economic performance, the new government elected in February 2005 decided to rethink the regulatory regime. In May 2005 a cross-departmental task force, the Office of Public Services and Reform, or Unidade de Coordenação da Modernazição Administrativa (UCMA), was created to oversee modernization and simplification of public services. One of the first issues tackled by this office was the simplification of the process of starting a business. As a result, the UCMA implemented the "On the Spot Firm" program, or Empresa na Hora (ENH), with the goal of decreasing the time, cost and complexity of starting a business.

The program allows the registration of single-shareholder companies, private limited companies, partnerships or public limited companies in a single office, the one-stop shop. However, it does not apply to governmental firms or firms involved in industries which require special authorization, permits or industry-specific requirements. ${ }^{10}$ Within one hour, an entrepreneur receives a corporate taxpayer number, social security number, commercial

\footnotetext{
${ }^{8}$ See, e.g., Mankiw and Whinston (1986) for a general discussion of free entry and social efficiency.

${ }^{9}$ For example, in 2005 a member country OECD required on average 6.5 procedures and 19.5 days, costing approximately 6.8 percent of the GNI per capita (World Bank, 2006). Djankov et al. (2002) present similar figures. In 2005 Portugal ranked 113 out of 155 countries in the Doing Business Ranking (World Bank, 2006), and if we consider only the waiting time to complete the registration procedures, it ranked 74 out of 85 countries studied by Djankov et al. (2002).

${ }^{10}$ Appendix A.1 lists all the industries that have to be registered by traditional procedures. The non-eligible
} 
registration, and declaration of business initiation. In order to increase the efficiency of the process, the UCMA developed standardized pre-approved articles of association, created lists of pre-defined firm names, and eliminated outdated start-up formalities such as the registration of company books and the legal obligation to provide public deeds.

The law for this administrative model was approved July 6, 2005 (with Decreto-Lei 111/2005), and at the same time six one-stop shops were piloted in four different counties, Coimbra, Aveiro, Moita and Barreiro. The shops generally took advantage of preexisting Trade Registry Offices and Business Formalities Centers by locating the shops in these facilities. Due to resource constraints, the program was not implemented simultaneously in all counties. Rather, over time the program expanded to other locations across the country. Table 1 presents the statistics on the timing and geographic variation of program adoption from 2005 to 2009 .

There was some resistance against the adoption of the program, particularly from the Association of Notaries, which in 2007 threatened to take the "On the Spot Firm" program to court, but these efforts did not slow the program's expansion. By the end of 2009, there were 164 one-stop shops located in 135 different counties (44 per cent of total counties). ${ }^{11}$ Although, the location of these shops are fairly dispersed throughout Portugal, the program targeted larger and economically important counties. At the same time that the program was implemented, Portugal had local elections for county chief executives. Political affiliation does not seem to play a significant role in program adoption. ${ }^{12}$

Because of the "On the Spot Firm" program, Portugal was considered the top reformer in business entry in 2005-2006, and was rewarded with the European Enterprise Award in the Red Tape Reducing category by the European Commission. ${ }^{13}$ Portugal's position on the international competitive rankings improved markedly, e.g., improving from the 74th to 40th percentile in the World Bank Red Tape Percentile Index, and rising to 33rd out of 155 countries in the annual Doing Business Ranking. Figure 1 compares the number and time of the procedures needed to register a firm before and after the introduction of the one-stop shop. After the reform, an entrepreneur could easily finish the registration process in one day, at a cost of approximately 360 Euro. $^{14}$

Two features of the program and institutional environment deserve additional discussion. First, at the end of 2008 there were three concurrent procedures to register a firm: traditional procedures, the "On the Spot Firm" program, and an online company incorporation (Empresa Online $).{ }^{15}$ However, the online company registration was initially only accessible to lawyers,

industries are mainly in the finance, insurance and transportation sector.

${ }^{11}$ Portugal is subdivided into 308 counties, which are approximately one quarter of the size of U.S. counties.

${ }^{12}$ Approximately 40 percent of the counties with one-stop shops had a chief executive that was from the government's party (PS) or from the main opposition party (PSD).

${ }^{13}$ World Bank (2006), for example, noted the changes: "In Portugal, now one of the fastest economies for start-up, an entrepreneur using the new fast-track service simply chooses a pre-approved name from the registry's website then goes to the one-stop shop to register the company," (p. 9).

${ }^{14}$ The total cost is 360 Euro or 300 Euro if the company's focus is information technology or research and development.

${ }^{15}$ This latter program was the result of an initiative from June 2006, in which the government launched a special regime for setting up companies via the Internet (Decreto-Lei 125/2006), with similar steps as the "On the Spot Firm" program. 
solicitors and notaries with a digital certification, and subsequently it only became available to individuals with the citizens card (cartão do cidadão) and electronic certification in the last trimester of 2009. ${ }^{16}$ Our data do not include information on the type of procedure used by entrepreneurs to register their firms. However, according to official information, more than 70 percent of new firms were established through the "On the Spot Firm" program until 2008. Traditional procedures and on-line registration were used much less frequently because of the cost and time of the former and the unavailability of the latter. Second, any individual or firm, anywhere in Portugal or abroad, can establish a firm in any onestop shop, regardless of the location of the company's headquarters. Although firms are allowed to register in one county and operate in another, this is not the usual procedure, and discussions with government officials strongly suggested that the fraction of firms registering outside their county of operation was trivially small. In short, over the time period we study, 2000-2008, there was considerable variation across regions and time in business registration costs and procedures. We will exploit this variation in policy using the rich data described below.

\section{$5 \quad$ Data and Descriptive Statistics}

The data for our empirical analysis come from an extraordinary matched employer-employee dataset (Quadros de Pessoal or SISED - Sistema de Informação de Salários, Emprego e Duração do Trabalho), built using a mandatory survey submitted annually by firms with at least one employee to the Portuguese Ministry of Employment and Social Security. These data include information on an average of 227,000 firms and two million individuals per year, covering virtually all employees and firms in the Portuguese private sector. As individuals and firms are cross-referenced by a unique identifier, the data make it possible to match founders with their firms characteristics. Each year, firms report their year of constitution, location, industry classification, number of employees, number of establishments, initial capital, and ownership structure. At the individual level, the data provide information on gender, age, date of hire, education, occupation, working hours, and earnings.

We supplement these data with information from other sources. Information on the opening date of each one-stop shop was obtained from the Institute of Registration and Notarization (Instituto dos Registos e do Notariado) at the Ministry of Justice. ${ }^{17}$ Countylevel data on inhabitants, gross domestic product, and an industrial production index are from the National Statistic Office.

Our matched employer-employee data includes 177,595 start-ups established in eligible industries for which we have a precise founding date that lies between 2000 and 2008. We use these firms and their characteristics to study the impact of the "On the Spot Firm" program on firm entry and job creation. For these new firms, we identify the founders and their

\footnotetext{
${ }^{16}$ The citizens card is a non-mandatory document, introduced in February 2007 (Lei 7/2007) with the goal of allowing individuals to identify themselves when dealing with computerized services and to authenticate electronic documents.

${ }^{17}$ The complete list of counties with an one-stop shop by December 2009 and their respective opening date is provided in Appendix A.2.
} 
background history. We exclude firms for which we could not identify at least one owner or the background history of the founder. ${ }^{18}$ We also restrict the sample to founders with age between 20 and 60 . In total, we ended up with 139,868 founders of 94,586 new firms. This entrepreneurs sample is used to evaluate the impact of the program on firm survival.

In addition, we draw a 30 percent random sample of all individuals who were employees in eligible firms between the period of 2000 and 2008, ${ }^{19}$ within the same age range (20 to 60 ) and with known labor market histories. Then we merge the latter sample with the entrepreneurs sample. This allows us to compare characteristics of firm founders and nonfounders in specific years. In total, we then have a sample of 5,071,627 individuals, of whom 33,958 are entrepreneurs. These data allow us to evaluate the impact of the program on the decision to become an entrepreneur.

Our basic empirical strategy, discussed below, is to compare county-level economic outcomes before and after the introduction of the one-stop shops. Table 2 provides various descriptive statistics for such counties. In first column we give statistics for the 12 months prior to the opening of the one-stop shop, in the second column we provide statistics for the 12 months after the opening, and the third column we record the difference. In general, the opening of a one-stop shop is associated with an increase in number of firms and jobs created (though this increase is statistically significant only in the former case). Firms established after the program introduction have fewer employees, and low subsequent probability of surviving in the first two years. In terms of the founder characteristics, after the program is introduced entrepreneurs are less likely to be male, are slightly older, and are less experienced (though the changes in the first two features are not statistically significant). To make the later point, we focused on two categories of entrepreneurs: "novice entrepreneurs," who have not previously established a firm, but who do have previous labor experience, and "habitual entrepreneurs," who have both previous entrepreneurial and labor experience. We notice that after the opening of one-stop shops, there is a three percent increase in the proportion of novice entrepreneurs and a two percent decline in habitual entrepreneurs.

\section{Empirical Methodology and Results}

In this section we present estimates of the impact of the Portuguese reform on entrepreneurial outcomes - entry, job creation, firm size and survival — using a simple differences-in-differences approach. Eligible firms and individuals in counties with one-stop shops constitute the "treatment group," which is compared to a "control group" with no one-stop shop. More precisely, we estimate regressions in which the outcome variable of interest is estimated as a function of indicator variables that measure seasonal effects, county-time fixed effects, and of course our key indicator variable that equals one when the reform takes place within a county. Our identification strategy relies, of course, on an assumption that the program is not being

\footnotetext{
${ }^{18}$ For the employees, the data include some cases in which the record changes in gender and year of birth. We consider observations with multiple changes in the gender or year of birth to be errors, corresponding to individuals whose identification number was not recorded, or wrongly identified by the respondent. We drop individuals whose gender and year birth change in more than 70 percent of the total number of observations.

${ }^{19}$ We exclude the year 2001 because there are no data available for workers that year.
} 
rolled out in a way that correlates with pre-existing trends in the dependent variables of interest. For example, our strategy would give misleading inferences if the one-stop shops were purposely introduced in locations that initially were experience rapid job growth. We conduct some analysis below that suggests our assumption is credible. As an initial check of this issue, though, we investigated whether "early adopting" counties (which established one-stop shops between July 2005 and June 2007) differed from "late adopting" counties (which established one-stop shops between July 2007 and December 2008) in terms of initial growth trends (2000 through 2004) of total sales, sales of new firms, number of firms, number of new firms and purchasing power. We find no significant difference between counties.

\subsection{Firm Entry and Job Creation}

We start by determining the effect of business registration reform on firm entry. Let $Y_{c m y}$ be the number of newly formed firms per 100,000 inhabitants in county $c$, month $m$ and year $y$. We estimate, for the 308 counties in Portugal and over the time period 2000 through 2008,

$$
Y_{c m y}=\sum_{m=1}^{12} \alpha_{m}+\sum_{c=1}^{308} \sum_{y=2000}^{2008} \nu_{c y}+\delta I_{m y}+\theta Z_{c m y}+\epsilon_{c m y}
$$

where $\alpha_{m}$ controls for seasonal effects in firm entry, ${ }^{20} \nu_{c y}$ are county/year fixed effects, $I_{m y}$ is a monthly index of industrial production for the country, which further controls for economic activity, and, $Z_{c m y}$ is the key variable of interest - an indicator variable that equals one at the opening month of the one-stop shop and all subsequent months (and zero otherwise). Notice that because of our inclusions of county/year fixed effects, identification here comes from comparison of firm entry rates within a particular county in months immediately before the introduction of the one-stop shop to the firm entry rates in the months immediately thereafter. Standard errors for this and all subsequent regressions are clustered at the county level.

Column (1) of Panel A in Table 3 presents estimates. Our theory leads us to expect the opening of one-stop shops to lead to an increase in firm entry, i.e., that the estimate of $\theta$ should be positive. In fact, we find that the introduction of the one-stop shop is associated with an increase in the number of new firms per 100,000 inhabitants of approximately two, which is an approximately 17 percent increase.

Panel B in Table 3 uses the same specification to examine the impact of the one-stop shop reform on initial employment. In this case, the dependent variable in (9) is the initial number of employees of start-ups at the county level (per 100,000 inhabitants). As predicted, the coefficient is positive; we estimate that the reform is associated with an increase in initial employment in new firms of 7 per 100,000, corresponding to an increase of approximately 22 percent.

As we have mentioned, the key to our identification strategy is an assumption that administrative decisions to the open one-stop shops in particular counties and time periods

\footnotetext{
${ }^{20}$ As it turns out, entry is generally stronger in the first three months of a year, slower in the summer, stronger in early fall, and slower again in November and December.
} 
are not correlated with existing trends in firm formation or economic growth within counties. As a means of checking this assumption we estimate the following variant of our baseline regression:

$$
Y_{c m y}=\sum_{m=1}^{12} \alpha_{m}+\sum_{c=1}^{308} \sum_{y=2000}^{2008} \nu_{c y}+\delta I_{m y}+\sum_{l=-10}^{11} \theta_{l} z_{l c}+\epsilon_{c m y}
$$

where $z_{l c}$ is a set of indicator variables for the 10 months prior to the opening of a one-stop shop and the 10 months after the opening of the one-stop shop. Thus, for instance, $z_{-1}$ is equal to one in the month prior to the opening of the one-stop shop (otherwise 0), while $z_{1}$ is equal to one for the month after the opening of the one-stop shop (otherwise 0 ). The only exception is $z_{11}$, which is equal to one for month 11 and for the months that follow. We set $\theta_{-1}$ to 0 (i.e., let that be the "omitted" indicator variable). Figure 2 and 3 plots the coefficients $\theta_{l}$, for firm entry and employment regressions, respectively.

Consider Figure 2. The coefficients on the "lags" are generally close to 0; using an F test, we cannot reject the hypotheses that $\hat{\theta}_{-10}, \ldots, \hat{\theta}_{-1}=0$. This suggests that on average, in the months leading up to the establishment of the one-stop shop there was no unusual trend in the establishment of new firms. This, in turn, gives us increased confidence in our identifying strategy. In contrast, in the month of the establishment of the one-stop shop, and the months that follow, we have positive and statistically significant coefficients, which we expect, given the estimates from our baseline regression (9). Our $F$ test easily rejects the null hypothesis that these coefficients jointly equal 0 . Figure 3 shows comparable results for our analysis of employment at newly established firms.

Some counties have more than one one-stop shop by the end of the sample period. We find that our results (here and in other specifications) do not qualitatively change when we exclude these counties from the "treatment" group. Another concern is that entrepreneurs in counties that border another county with a one-stop shop might cross borders to register in the other county, then operate in the county of residence of the entrepreneur. This would lead us to underestimate the causal effect of the one-stop shop on observed effects, because some one-stop shops would "treat" individuals in the "control" counties. Conversations with officials in the one-stop shop program indicated that it was very rare for entrepreneurs to register in a county other than their county of operation. We experimented with aggregating counties where this border-crossing was more likely, and these alternative specifications produce stronger results than those reported here.

\subsection{Firm Characteristics}

Our theory leads us to believe that any impact of the reform - the establishment of the one-stop shops - should be found in "marginal firms," which in our theory are also small firms. So we estimate our key regression (9) but for firms categorized by the firm's initial size. Columns (2) to (5) of Panel A in Table 3 report the coefficient when we consider the number of firms with one, two, three to five, and more than five employees, respectively. Our estimates indicate statistically significant increases in the number of newly established firms with two employees, and three to five employees, but no statistically significant increase in larger firms. 
Next, the number of new firms is broken down into ten sectors: agriculture, construction, high-technology industries, low technology industries, utilities, wholesale retail, retail trade, services and communities. ${ }^{21}$ Table 4 presents the results for this analysis, again using (9). The estimated positive impact of the reform is found to operate in three sectors: agriculture, construction and retail trade.

\subsection{Firm Survival}

As we mention in our paper's introduction, a distinctive feature of our data is the ability to examine the impact of the reform on the survival of newly-formed firms. Our approach is to examine the two-year survival rate, in which $S_{\text {iflcmy }}$ is firm survival for founder $i$ in firm $f$, industry $l$, county $c$, month $m$ and year $y$. This dependent variable is 1 if the start-up is still operating after two years, and 0 if not. It is taken to be a function of observables, as follows:

$$
S_{i f l c m y}=\sum_{m=1}^{12} \alpha_{m}+\sum_{c=1}^{308} \sum_{y=2000}^{2008} \nu_{c y}+\sum_{l=1}^{29} \lambda_{l}+\omega S_{f}+\tau X_{i}+\theta Z_{c m y}+\delta I_{m y}+\epsilon_{i f l c m y}
$$

where again we have indicators for month, year-county fixed effects, and now also two-digit industry fixed effects for 29 categories $\lambda_{l}$. We also have a variable that gives the firm's initial size, $S$. We include also a vector founder characteristics $X$ : gender, which equals 1 for men, 0 for women; four indicator variables for the founder's age, partitioned at 20, 30, 40, and 50; an "industry experience" variable which equals 1 for founders that previously work on the same four-digit industry digit code, 0 otherwise; and education, which is taken to be "very low" for those never completing elementary school, "low" for those that attended junior high school, "medium" for those with a high school diploma or equivalent, and "high" for those reporting bachelor's degree or more advanced degree. In reporting the estimated coefficients, our omitted categories are founders aged 20-29 and with "very low" education.

Table 5 gives estimates. We notice that in general start-up firm survival is higher for initially larger firms, and for firms founded by experienced individuals, by men (in comparison to women), by relatively older individuals, and by relatively well educated individuals. Importantly, there is a substantial estimated impact associated with the one-stop shop program. In comparison with other start-ups, firms established in the months after the availability of the one-stop shop program had two year survival rates that are approximately four percentage points lower.

\footnotetext{
${ }^{21}$ We use the definition of OECD (2002) to divide firms into high-technology and low-technology industries. "High-technology industries" include the following sectors: pharmaceuticals, office and computing machinery, radio, TV and communication equipment, medical, precision and optical equipment, aircraft and spacecraft, chemicals excluding pharmaceuticals, machinery and equipment, electrical machinery and apparatus, motor vehicles and trailers, railroad and transport equipment. "Low-technology industries" include coke, refined petroleum products and nuclear fuel, rubber and plastic products, other non-metallic mineral products, basic metals, fabricated metal products except machinery and equipment, building and repairing ships and boats, food products, beverage and tobacco, textile and textile products, leather and footwear, wood, pulp, paper products, printing and publishing, and recycling. We acknowledge that this is a rough taxonomy; the low-technology category could include some technologically progressive firms and vice versa.
} 
As in the analyses presented above, we also estimate the impact of the one-stop shop program on our survival variable, using estimates for lag and lead months. Figure 4 plots the coefficients on the lag and lead indicator variables, which were constructed using the same methodology as presented in Section 6.1. As can be seen in Figure 4, the fraction of surviving start-ups is close to zero before the opening of the one-stop shop and then it becomes jointly significantly negative from months 0 to $>10$.

\subsection{Entrepreneur Characteristics}

In this last section, we explore the effect of the one-stop program by estimating an equation in which the dependent variable is the probability that any individual in our data founds a start-up firm in a given year. Specifically, we start with the simple linear probability model:

$$
E_{i c y}=\sum_{y=2000}^{2008} \beta_{y}+\sum_{c=1}^{308} \gamma_{c}+\sum_{n=1}^{30}+\delta G_{n y}+\theta Z_{c y}+\tau X_{i}+\epsilon_{i c y}
$$

where $E_{i l c y}$ is an indicator variable that equals 1 if individual $i$ establishes a firm in county $c$ and year $y$, and 0 if that individual does not open a firm. We have also control for economic activity with a measure of gross domestic product (GDP), $G_{n}$, for 30 NUTS ("Nomenclature of Unit for Territorial Statistics") regions defined for Portugal. We include also a vector of individual characteristics $X_{i}$ (measures of age, gender, and education). Finally, $Z_{c y}$ is an indicator variable equal to 1 if there is a one-stop shop in county $c$ in year $y$ for at least part of the year. ${ }^{22}$ We remind the reader that these results are based on a 30 percent random sample of the database in which there are more than five million individuals, but fewer than 34,000 of these individuals transition into entrepreneurship. In other words, less than 0.68 percent $(0.0068)$ of the sample starts a new firm; our econometric estimates should be evaluated in light of this feature of the sample.

The estimates for this specification are presented in Column (1) of Table 6. Given results above, we are not surprised that the presence of a one-stop shop is associated with an increase in the probability an individual becomes an entrepreneur. Given the small fraction of the sample that ever becomes an entrepreneur, the coefficient on the One-Stop Shop dummy is associated with an marginal increase of about 9.2 percent. As for demographic and education variables, we can infer that male, middle aged (age between 30 and 39), and well-educated individuals are relatively more likely to transition into entrepreneurship than are other individuals.

Our model predicts that entry regulation reform leads to an increase in the entry of "marginal entrepreneurs." To evaluate that claim we interact each of the demographic and educational variables with $Z_{c y}$ (our indicator that the reform has occurred in the county in that year) and add these interactions to Equation (12). The coefficient estimates are reported in Column (2) of Table 6. These results suggest that the entrepreneurs induced into the market by the establishment of the one-stop shop are from demographic categories that were previously least likely to initially be entrepreneurs. Relative to the omitted category

\footnotetext{
${ }^{22}$ Our data for this regression is annual, so we cannot look at within-year effects as in the analyses above.
} 
(very low educated individuals), the fraction of highly educated entrepreneurs decreases by 0.4 percent. Similarly, marginal entrants appear to be older (individuals aged 40-50 and 50-60) and are less likely to be male.

These results, combined with the evidence presented above - that regulation reform is associated with the entry of firms that are less likely to survive to the two-year mark, provide some support for the argument that the reduced entry regulation disproportionately induced marginal, relatively low-ability individuals to establish businesses.

\section{Conclusion}

This paper uses Portuguese micro-level data to analyze the effects of a program that substantially reduced entry regulation for business. The reform, which introduced one-stop shops in counties throughout the country, appears to have had meaningful effects on start-up entry, performance, and survival.

By comparing counties with and without one-stop shops, we find that the program increases the number of start-ups in eligible industries by approximately 17.2 percent. This increase is disproportionately driven by entrepreneurs who are relatively older, more female and less educated. Based on our estimates, the reform is associated with an increase in seven new jobs per month per 100,000 inhabitants (a 21.7 percent increase). These jobs are created primarily in the agricultural, retail trade and construction sectors. We also find that the start-ups created in response to the reform are relatively smaller and less likely to survive in their first two years than firms founded in the absence of the reform.

We view the results as entirely consistent with the theoretical model of entrepreneurship set out in this paper. Inspired by the seminal work of Lucas (1978), we show that artificial entry costs deter entrepreneurship at the margin. Reform, i.e., the reduction of entry costs, is predicted to affect entrepreneurship and job formation in just the way we in fact observe. Our results, then, can be seen as broadly consistent with the "public choice" approach to entry regulation, which emphasizes the inefficiencies associated with entry regulation, and argues for the relaxation of such regulation.

In the Portuguese case, the reform was substantial. Portugal undertook one of the most complete and thorough deregulation efforts of any country in Western Europe, moving up 80 places in the World Bank's Doing Business index and winning international accolades for the government in the process. As it was implemented across the country, this reform appears to have induced statistically significant increases in firm formation and job creation.

Having said all that, a more detailed examination of the kind of firms and jobs created by this reform suggests a more nuanced picture of its effects. The new firms whose entry is associated with reform are decidedly low-tech, headed by inexperienced entrepreneurs, and are less likely to survive than firms formed when barriers were higher. Portugal's high entry barriers were a significant impediment to low quality firms and marginal entrepreneurs, but apparently represented less of an impediment to high quality firms. The overall social gains resulting from the reform are limited by the quality of the firms it has created, at least so 
far. Reform has brought benefits, but it is hardly the magic bullet some policymakers may have anticipated.

This conclusion comes with some obvious caveats. We have deliberately adopted a conservative empirical specification that attempts to control as completely as possible for differential trends in firm creation at the county level; the conservative nature of our approach could bias our estimates downward. In addition, this reform was implemented in a difficult macroeconomic context. Portugal emerged from recession in 2003, but growth since then has been weak, consumption and investment have remained depressed, and unemployment has been high. If and when the macroeconomic environment improves, the new administrative regime could have a stronger effect on firm and job creation than is evidenced by our analysis. Unfortunately, given the depth of Portugal's current economic difficulties, it may be some time before scholars will be in a position to evaluate this possibility. 


\section{References}

Aghion, Philippe, Robin Burgess, Stephen J. Redding, and Fabrizio Zilibotti. "The Unequal Effects of Liberalization: Evidence from Dismantling the License Raj in India." American Economic Review 98, 4: (2008) 1397-1412.

Alesina, Alberto, Silvia Ardagna, Giuseppe Nicoletti, and Fabio Schiantarelli. "Regulation and Investment." Journal of the European Economic Association 3, 4: (2005) 791-825.

Barseghyan, Levon. "Entry Costs and Cross-country Differences in Productivity and Output." Journal of Economic Growth 13, 2: (2008) 145-167.

Bertrand, Marianne, and Francis Kramarz. "Does Entry Regulation Hinder Job Creation? Evidence from the French Retail Industry." Quarterly Journal of AEconomics 117, 4: (2002) 1369-1413.

Bjørnskov, Christian, and Nicolai J. Foss. "Economic Freedom and Entrepreneurial Activity: Some Cross-country Evidence." Public Choice 134, 3: (2008) 307-328.

Bruhn, Miriam. "License to Sell The Effect of Business Registration Reform on Entrepreneurial Activity in Mexico." The World Bank - Policy Research Working Paper 4538.

Chari, Amalavoyal V. "License Reform in India: Theory and Evidence." Department of Economics, Yale University, New Haven, Connecticut .

Ciccone, Antonio, and Elias Papaioannou. "Red Tape and Delayed Entry." Journal of the European Economic Association 5, 2-3: (2007) 444-458.

De Soto, Hernando. The Other Path: The Invisible Revolution in the Third World. New York: Harper \& Row, 1989.

Desai, Mihir A., Paul A. Gompers, and Josh Lerner. "Institutions, Capital Constraints and Entrepreneurial Firm Dynamics: Evidence from Europe." National Bureau of Economic Research Working Paper working paper 10165.

Djankov, Simeon. "A Response to Is Doing Business Damaging Business." Working Paper, World Bank . (2009) 183.

Djankov, Simeon, Rafael La Porta, Florencio Lopez de Silanes, and Andrei Shleifer. "The Regulation of Entry." Quarterly Journal of Economics 117: (2002) 224-232.

Djankov, Simeon, Caralee McLiesh, and Rita M. Ramalho. "Regulation and Growth." Economics Letters 92, 3: (2006) 395-401.

Dreher, Axel, and Martin Gassebner. "Greasing the Wheels of Entrepreneurship." The Impact of Regulations and Corruption on Firm Entry . 
Dulleck, Uwe, Paul Frijters, and Rudolf Winter-Ebmer. "Reducing Start-up Costs for New Firms: The Double Dividend on the Labor Market." Scandinavian Journal of Economics 108, 2: (2006) 317-337.

Fisman, Raymond, and Virginia Sarria-Allende. "Regulation of Entry and the Distortion of Industrial Organization." National Bureau of Economic Research Working Paper 10929 .

Kaplan, David S., Eduardo Piedra, and Enrique Seira. "Entry Regulation and Business Startups: Evidence from Mexico." World Bank Policy Research Working Paper 4322.

Klapper, Leora, Luc Laeven, and Raghuram G. Rajan. "Entry Regulation as a Barrier to Entrepreneurship." Journal of Financial Economics 82, 3: (2006) 591-629.

Lucas, Robert E. "On the Size Distribution of Business Firms." The Bell Journal of Economics 9, 2: (1978) 508-523.

Mankiw, Grefory N., and Michael D. Whinston. "Free Entry and Social Inefficiency." Rand Journal of Economics 17, 1: (1986) 48-58.

Monteiro, Joana C. M., and Juliano J. Assunção. "Outgoing the Shadows: Estimating the Impact of Bureaucracy Simplification and Tax Cut on Formality and Investment." Pontifícia Universidáde Católica, Department of Economics .

OECD. "OCDE Science, Technology and Industry Outlook." Technical report, OECD, Paris, 2002.

Peltzman, Sam. "Toward a More General Theory of Regulation." The Journal of Law and Economics 19, 2: (1976) 211.

Pigou, Arthur C. The Economics of Welfare. London: Macmillan and Co., 1938.

Posner, Richard A. "The Social Costs of Monopoly and Regulation." The Journal of Political Economy 83, 4: (1975) 807.

Prantl, Susanne, and Alexandra Spitz-Oener. "How Does Entry Regulation Influence Entry into Self-employment and Occupational Mobility?" Economics of Transition 17, 4: (2009) 769-802.

Schumpeter, Joseph A. The Theory of Economic Development: An Inquiry into Profits, Capital, Credit, Interest, and the Business Cycle. Cambridge: Harvard University Press, 1934.

Stigler, George J. "The Theory of Economic Regulation." The Bell Journal of Economics and Management Science 2, 1: (1971) 3-21.

World Bank. "Doing Business in 2007: How to Reform." Technical report, World Bank, Washington D.C., 2006.

Yakovlev, Evgeny, and Ekaterina V. Zhuravskaya. "Deregulation of Business." CEFIR/ NES Working Paper 97. 
Figure 1: Start-up Procedures in Portugal, Before and After the "On the Spot Firm" Program

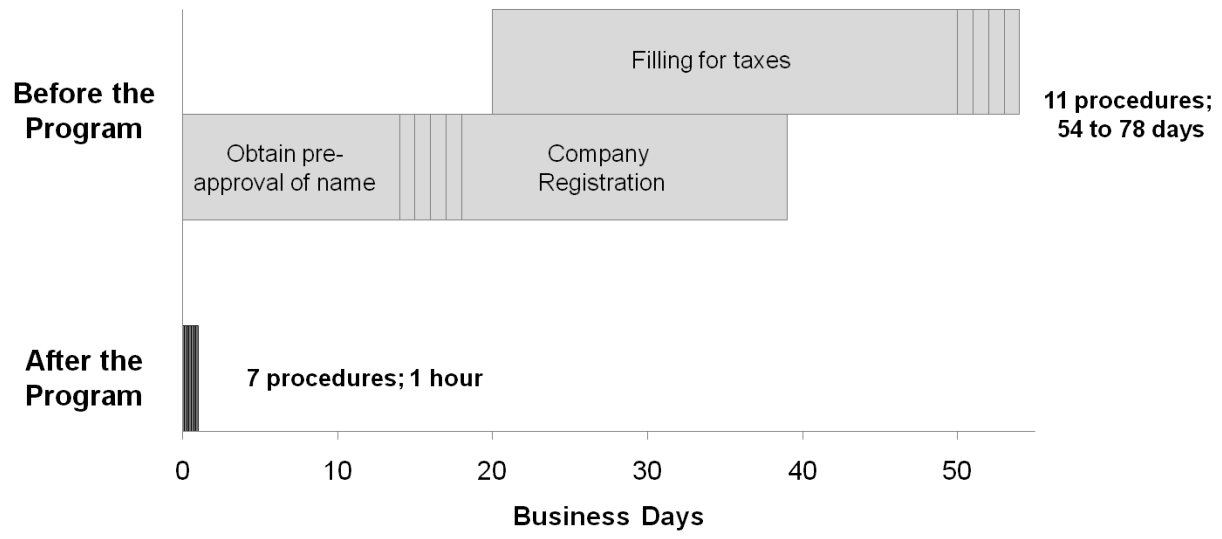

Note: The registration procedures are lined up sequentially. Business days required to complete each procedure are measured against the horizontal scale. 
Figure 2: Coefficients on the Program Month Dummies for Firm Entry

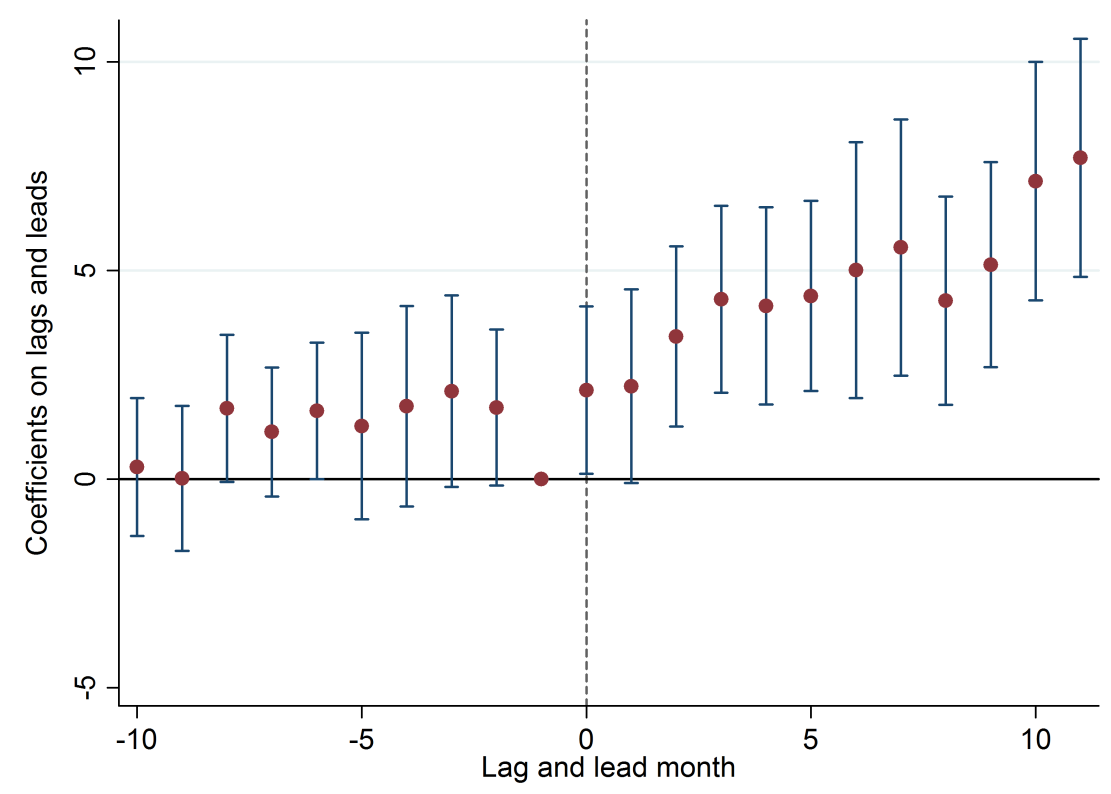

Note: The figure plots the coefficients $\theta_{l}$ from Equation (10), with a dependent variable, number of firms established in a county per 100,000 inhabitants. Vertical lines are the 95 percent confidence intervals for the coefficients. The $F$ statistic for pre period is 1.122 (p-value is 0.347 ); $F$ test statistic for post period is 2.839 (p-value is 0.0011 ). 
Figure 3: Coefficients on the Program Month Dummies for Job Creation

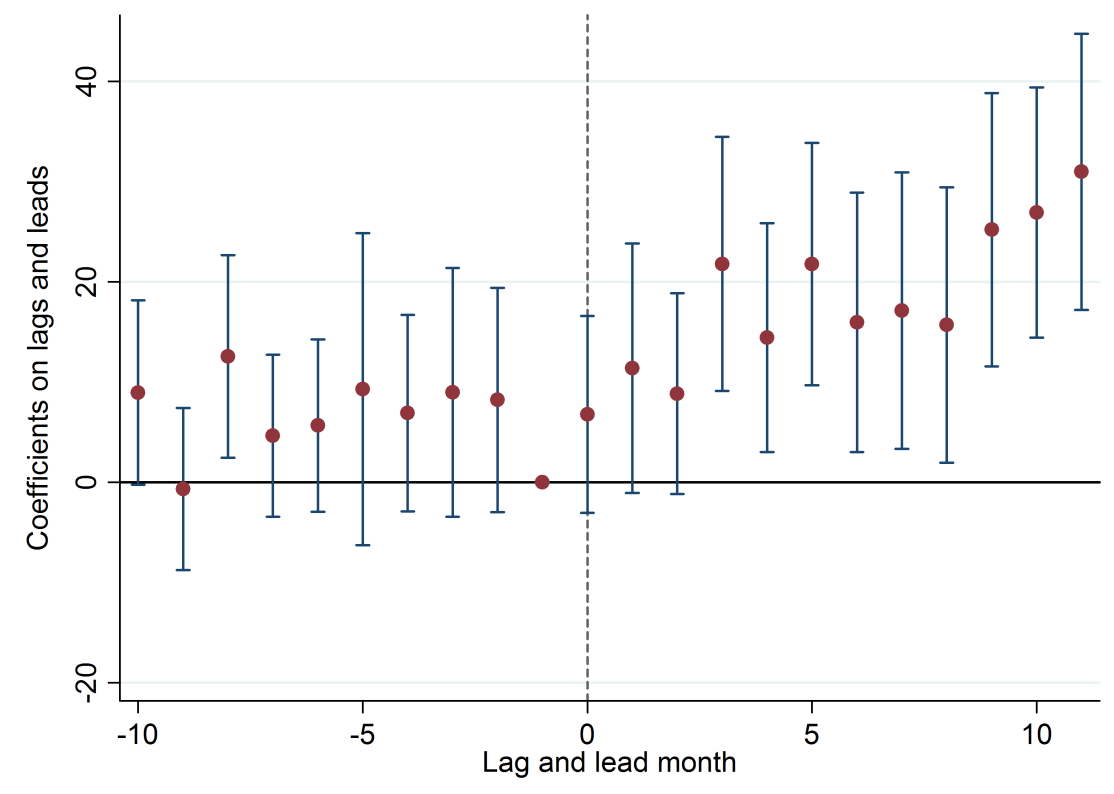

Note: The figure plots the coefficients $\theta_{l}$ from Equation (10), with a dependent variable, number of employees at newly-established firms in a county per 100,000 inhabitants. Vertical lines are the 95 percent confidence intervals for the coefficients. The $F$ statistic for pre period is 1.578 (p-value is 0.121 ); $F$ test statistic for post period is 2.889 (p-value is 0.0085 ). 
Figure 4: Coefficients on the Program Month Dummies for Two Year Survival

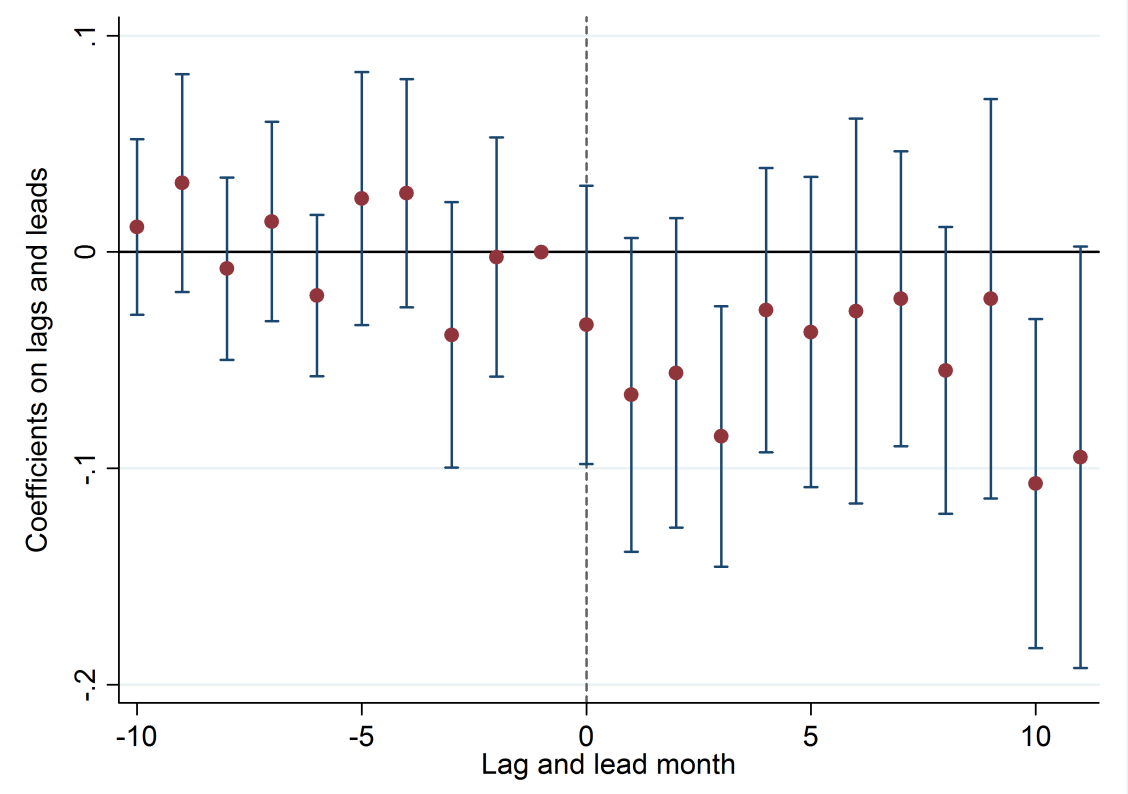

Note: The figure plots the coefficients $\theta_{l}$ from Equation (11), with an indicator dependent variable equal to 1 if the firm survived two years. Vertical lines are the 95 percent confidence intervals for the coefficients. The $F$ statistic for pre period is 0.65 (p-value is 0.756 ); $F$ test statistic for post period is 3.69 (p-value is less than 0.001 ). 
Table 1: One-Stop Shop Program Adoption

\begin{tabular}{lcccccc}
\hline & $\mathbf{2 0 0 5}$ & $\mathbf{2 0 0 6}$ & $\mathbf{2 0 0 7}$ & $\mathbf{2 0 0 8}$ & $\mathbf{2 0 0 9}$ & Total \\
\hline Number of shops & 20 & 28 & 31 & 36 & 49 & $\mathbf{1 6 4}$ \\
Number of counties implementing & 13 & 24 & 28 & 34 & 46 & $\mathbf{1 3 5}$ \\
Number of counties $>1$ shop & 6 & 3 & 1 & 2 & 0 & $\mathbf{1 2}$ \\
\hline
\end{tabular}

Note: The following counties have more than one one-stop shop: Aveiro, Braga, Castelo Branco, Coimbra, Guarda, Leiria, Lisbon, Loulé, Odivelas, Porto, Setúbal, and Viseu. 
Table 2: Descriptive Statistics

\begin{tabular}{lccc} 
& Before & After & Diff \\
\hline A. Firm Entry and Job Creation & \\
\hline Number of Firms & 191.0 & 214.7 & $23.69^{*}$ \\
& $(8.916)$ & $(10.89)$ & $(14.07)$ \\
Job Creation & 57 & 57 & 114 \\
& 600.3 & 630.8 & 30.45 \\
& $(39.33)$ & $(40.66)$ & $(56.57)$ \\
& 57 & 57 & 114
\end{tabular}

\section{B. Firm Characteristics}

\begin{tabular}{|c|c|c|c|}
\hline Size & 3.735 & 3.493 & $-0.241^{* *}$ \\
\hline & $(0.0816)$ & $(0.0600)$ & $(0.101)$ \\
\hline & 6186 & 6981 & 13167 \\
\hline 2 Year Survival & 0.833 & 0.801 & $-0.0329 * *$ \\
\hline & $(0.0109)$ & $(0.0108)$ & $(0.0153)$ \\
\hline & 1165 & 1379 & 2544 \\
\hline C. Entrepreneur & laracteris & & \\
\hline Proportion Male & 0.667 & 0.659 & -0.00714 \\
\hline & $(0.00599)$ & $(0.00567)$ & $(0.00825)$ \\
\hline & 6186 & 6981 & 13167 \\
\hline Average Age & 35.82 & 35.86 & 0.0375 \\
\hline & $(0.114)$ & $(0.109)$ & $(0.158)$ \\
\hline & 6186 & 6981 & 13167 \\
\hline Proportion Novice & 0.548 & 0.581 & $0.0336^{* * *}$ \\
\hline & $(0.00646)$ & $(0.00604)$ & $(0.00884)$ \\
\hline & 5943 & 6668 & 12611 \\
\hline Proportion Habitual & 0.168 & 0.152 & $-0.0158^{* *}$ \\
\hline & $(0.00485)$ & $(0.00439)$ & $(0.00654)$ \\
\hline & 5943 & 6668 & 12611 \\
\hline
\end{tabular}

Note: The table reports various descriptive statistics for counties that opened one-stop shops in a 12-month window before the shop opened and a 12-month window after the shop opened. Robust standard errors are in parentheses and the number of observations is presented below. $* * *$ denotes statistical significance at $1 \%, * *$ significance at $5 \%,{ }^{*}$ significance at $10 \%$. 
Table 3: Impact of "On the Spot Firm" Program on Entry and Job Creation

\begin{tabular}{|c|c|c|c|c|c|}
\hline \multicolumn{6}{|l|}{ Panel A. Firm Entry } \\
\hline & All Firms & One Employee & Two Employees & $\begin{array}{l}\text { Three to Five } \\
\text { Employees }\end{array}$ & $\begin{array}{l}\text { More than Five } \\
\text { Employees }\end{array}$ \\
\hline & $(1)$ & $(2)$ & $(3)$ & $(4)$ & $(5)$ \\
\hline One-Stop Shop $(Z=1)$ & $\begin{array}{c}1.999^{* * *} \\
(0.655)\end{array}$ & $\begin{array}{c}0.544 \\
(0.426)\end{array}$ & $\begin{array}{c}0.585^{* *} \\
(0.241)\end{array}$ & $\begin{array}{c}0.611^{* *} \\
(0.262)\end{array}$ & $\begin{array}{c}0.259 \\
(0.212)\end{array}$ \\
\hline Econ. Activity Index & $\begin{array}{l}0.156^{* *} \\
(0.0755)\end{array}$ & $\begin{array}{c}0.0327 \\
(0.0285)\end{array}$ & $\begin{array}{c}0.0544^{* * *} \\
(0.0108)\end{array}$ & $\begin{array}{l}0.0541^{* *} \\
(0.0228)\end{array}$ & $\begin{array}{c}0.0152 \\
(0.0194)\end{array}$ \\
\hline Observations & 32648 & 32648 & 32648 & 32648 & 32648 \\
\hline Adjusted R-squared & 0.654 & 0.406 & 0.346 & 0.390 & 0.307 \\
\hline \multicolumn{6}{|l|}{ Panel B. Job Creation } \\
\hline & $\begin{array}{c}\text { Initial } \\
\text { Employment }\end{array}$ & & & & \\
\hline & $(1)$ & & & & \\
\hline One-Stop Shop $(Z=1)$ & $\begin{array}{l}6.616^{*} \\
(3.386)\end{array}$ & & & & \\
\hline Econ. Activity Index & $\begin{array}{l}0.545^{*} \\
(0.316)\end{array}$ & & & & \\
\hline Observations & 32648 & & & & \\
\hline Adjusted R-squared & 0.496 & & & & \\
\hline
\end{tabular}

Note: Panel A and B report the estimates of coefficients in (9). The dependent variable is the number of new firms established per 100,000 inhabitants. Columns (2) to (5) conducts the analysis for firms by initial size. In Panel B, the dependent variable is the number of employees at start-up firms per 100,000 inhabitants. Month and county-year fixed effects are included but not reported. Standard errors clustered at the county level are in parentheses. *** denotes statistical significance at $1 \%,{ }^{* *}$ significance at $5 \%,{ }^{*}$ significance at $10 \%$. 


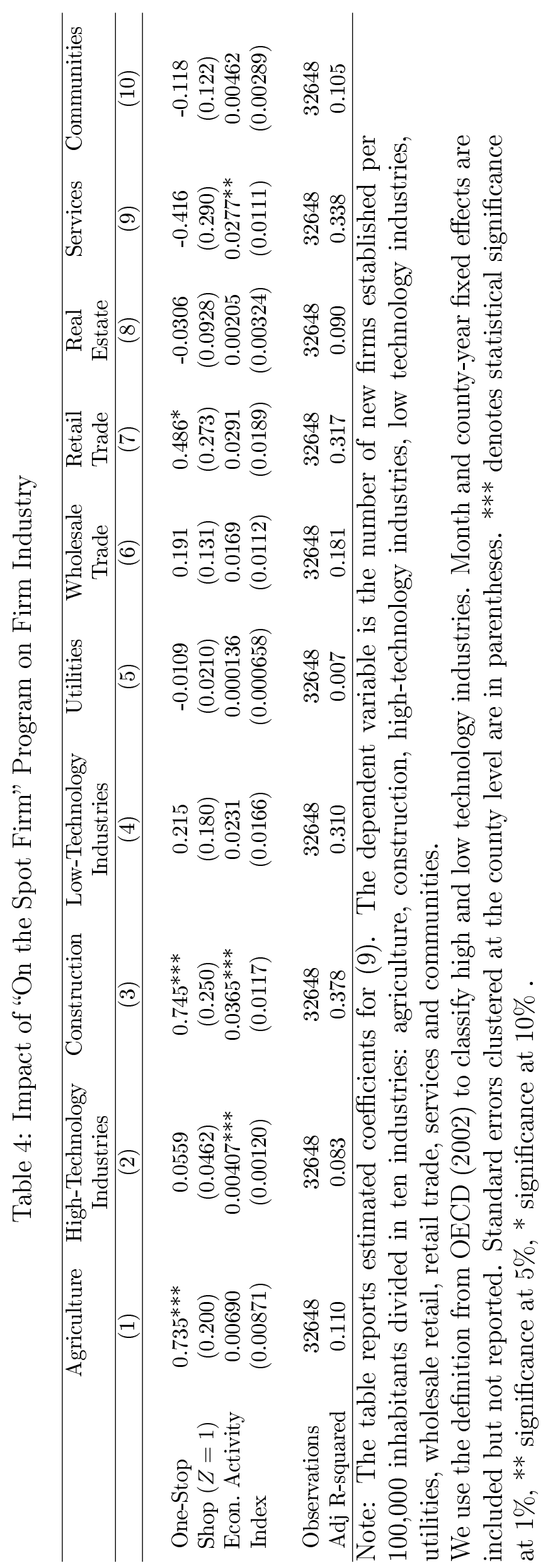


Table 5: Impact of "On the Spot Firm" Program on Survival

\begin{tabular}{lc}
\hline & Two Year Survival \\
\hline & $(1)$ \\
One-Stop Shop $(Z=1)$ & $-0.0444^{* *}$ \\
& $(0.0209)$ \\
Ind & $0.0153^{* * *}$ \\
& $(0.00303)$ \\
Size & $0.00302^{* * *}$ \\
& $(0.000259)$ \\
Gender & $0.00765^{* * *}$ \\
& $(0.00229)$ \\
Age 30-39 & $0.0268^{* * *}$ \\
& $(0.00308)$ \\
Age 40-49 & $0.0321^{* * *}$ \\
& $(0.00311)$ \\
Age 50-60 & $0.0410^{* * *}$ \\
& $(0.00398)$ \\
Low education & 0.00481 \\
& $(0.00343)$ \\
Medium education & 0.00612 \\
& $(0.00458)$ \\
High education & $0.0408^{* * *}$ \\
Econ. Activity Index & $(0.00482)$ \\
Constant & 0.000168 \\
& $(0.000750)$ \\
Observations & $0.911^{* * *}$ \\
Adjusted R-squared & $(0.0768)$ \\
& \\
\end{tabular}

Note: The table reports estimated coefficients for (11). The dependent variable is two year survival ( 1 if the firm survived, 0 if not). Month, county-year, and industry fixed effects (two digit level) are included but not reported. Standard errors clustered at the county level are in parentheses. ${ }^{* * *}$ denotes statistical significance at $1 \%,{ }^{* *}$ significance at $5 \%,{ }^{*}$ significance at $10 \%$. 
Table 6: Impact of "On the Spot Firm" Program on Type of Entrepreneurs

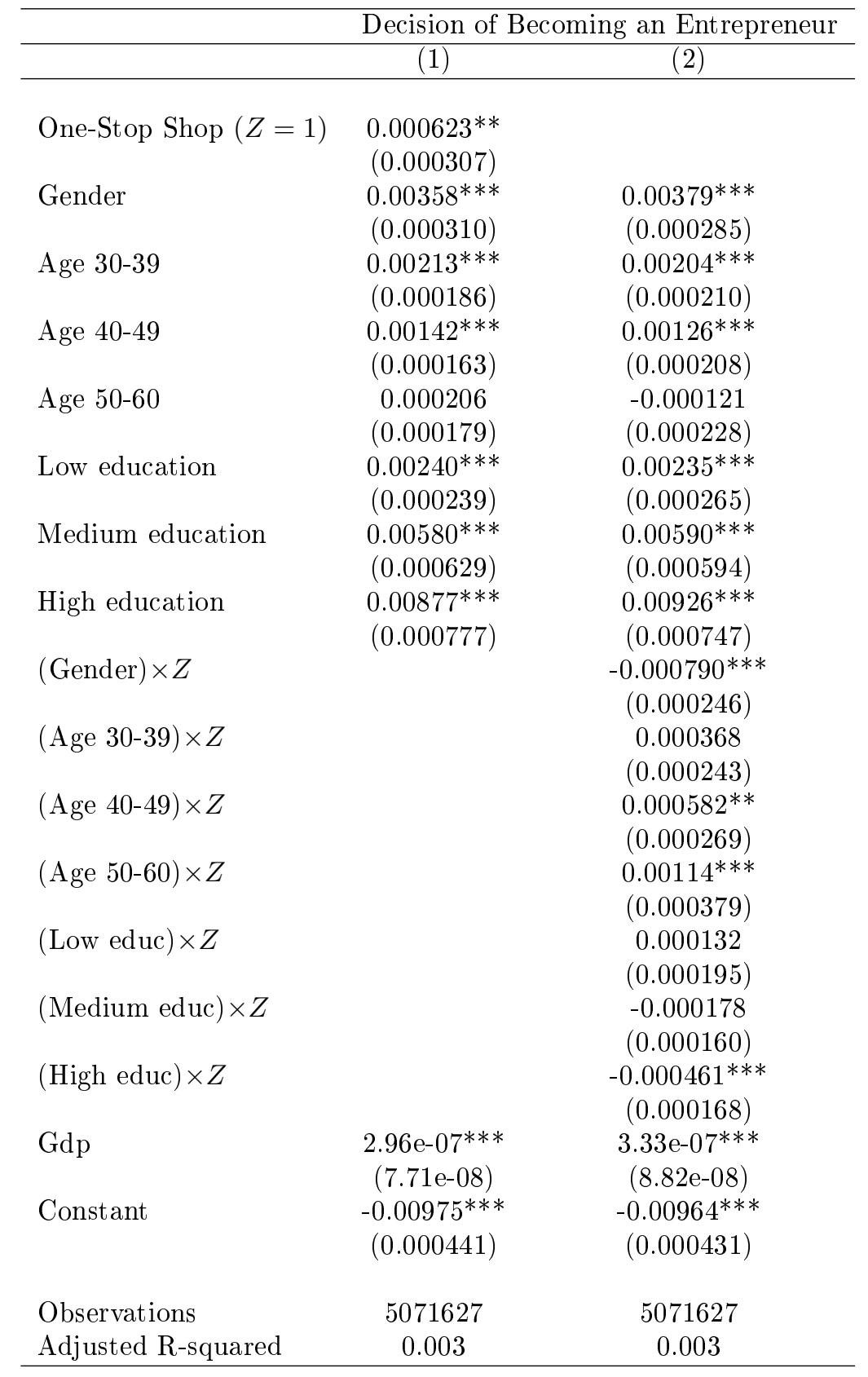

Note: The table reports estimated coefficients for (12). The dependent variable equals 1 if the individual is an entrepreneur, 0 otherwise. Year and county fixed effects are included but not reported. Standard errors clustered at the county level are in parentheses. *** denotes statistical significance at $1 \%,{ }^{*}$ significance at $5 \%,{ }^{*}$ significance at $10 \%$. 


\section{A Appendix}

\section{A.1 List of Non-Eligible Industries}

\begin{tabular}{|c|c|}
\hline Division & Non-eligible industries and occupations \\
\hline Manufacturing & Arms and Ammunitions \\
\hline \multirow[t]{9}{*}{ Transportation and Communication } & Railroad Transportation \\
\hline & Local and Suburban Transit and Interurban Passenger Transportation \\
\hline & Motor Freight Transportation \\
\hline & Water Transit \\
\hline & Transportation by Air \\
\hline & Transportation Services (e.g. storage, administrative services) \\
\hline & Telephone Communications \\
\hline & Television Broadcasting Stations \\
\hline & Journalism \\
\hline \multirow[t]{6}{*}{ Retail Trade } & Automotive Dealers \\
\hline & Gasoline Service Stations \\
\hline & Catering \\
\hline & Drug Stores \\
\hline & Retail of Arms and Ammunitions \\
\hline & Retail of Electric Energy \\
\hline \multirow[t]{7}{*}{ Finance, Insurance, And Real Estate } & Commercial Banks \\
\hline & Security Brokers and Dealers \\
\hline & Pension Funds \\
\hline & Insurance Carriers \\
\hline & Insurance Agents \\
\hline & Investment Offices \\
\hline & Real Estate \\
\hline \multirow[t]{17}{*}{ Services } & Hotels, Boarding Houses and Spas \\
\hline & Detective and Guard Services \\
\hline & Automobile Inspections \\
\hline & Professional Sports Clubs \\
\hline & Gambling Establishments and Casinos \\
\hline & Legal Services \\
\hline & Professional Schools \\
\hline & Employment Services/ Agencies \\
\hline & Vocational Training \\
\hline & Driving Schools \\
\hline & Zoological Parks \\
\hline & Accounting, Auditing, and Bookkeeping Services \\
\hline & Management Services and Holdings \\
\hline & Towing Services \\
\hline & Car Rental Services \\
\hline & Car Inspection Service \\
\hline & Funeral Houses \\
\hline Public Administration & All \\
\hline
\end{tabular}




\section{A.2 One-Stop Shop Opening Dates}

\begin{tabular}{|c|c|c|c|}
\hline One-Stop Shop & County & Openning Date & Closing Date \\
\hline CRC Aveiro & Aveiro & Jul 14, 2005 & \\
\hline CRC Barreiro & Barreiro & Jul 14, 2005 & \\
\hline CRC Coimbra & Coimbra & Jul 14,2005 & \\
\hline CRC Moita & Moita & Jul 14,2005 & \\
\hline CFE Aveiro & Aveiro & Jul 14,2005 & \\
\hline CFE Coimbra & Coimbra & Jul 14, 2005 & \\
\hline CRC Beja & Beja & Nov 15,2005 & \\
\hline CRC Braga & Braga & Nov 15,2005 & \\
\hline CRC Bragança & Bragança & Nov 15,2005 & \\
\hline CRC Guarda & Guarda & Nov 15,2005 & \\
\hline CRC V.N. Gaia & Vila Nova de Gaia & Nov 15,2005 & \\
\hline CFE Braga & Braga & Nov 15,2005 & \\
\hline CRC Loulé & Loulé & Dec 27, 2005 & \\
\hline CRC Sintra & Sintra & Dec 27,2005 & \\
\hline CRC Viseu & Viseu & Dec 27, 2005 & \\
\hline RNPC Lisboa & Lisboa & Dec 27, 2005 & \\
\hline CFE Lisboa I & Lisboa & Dec 27,2005 & Feb 8, 2008 \\
\hline CFE Lisboa II & Lisboa & Dec 27, 2005 & \\
\hline CFE Loulé & Loulé & Dec 27, 2005 & \\
\hline CFE Viseu & Viseu & Dec 27, 2005 & \\
\hline CRC Évora & Évora & Jan 27,2006 & \\
\hline CRC Leiria & Leiria & Jan 27, 2006 & \\
\hline CRC Santarém & Santarém & Jan 27,2006 & Jan 20, 2009 \\
\hline CRC Viana do Castelo & Viana do Castelo & Jan 27, 2006 & \\
\hline CFE Leiria & Leiria & Jan 27,2006 & \\
\hline CRC Castelo Branco & Castelo Branco & Feb 24, 2006 & \\
\hline CRC Portalegre & Portalegre & Feb 24, 2006 & \\
\hline CRC Setúbal & Setúbal & Feb 24, 2006 & \\
\hline CRC Vila Real & Vila Real & Feb 24, 2006 & \\
\hline CFE Setúbal & Setúbal & Feb 24, 2006 & \\
\hline CRC Porto & Porto & Mar 31, 2006 & \\
\hline CFE Porto & Porto & Mar 31, 2006 & \\
\hline CFE Funchal & Funchal & Apr 11, 2006 & \\
\hline CRC Gondomar & Gondomar & Apr 28, 2006 & \\
\hline CRC Ponta Delgada & Ponta Delgada & Apr 28, 2006 & \\
\hline CRC Faro & Faro & May 31,2006 & \\
\hline CRC Angra do Heroísmo & Angra do Heroísmo & Jun 1,2006 & \\
\hline CRC Maia & Maia & Jun 1,2006 & \\
\hline $1^{\mathrm{a}}$ CRPC Guimarães & Guimarães & Sep 29, 2006 & \\
\hline CRPC São João da Madeira & São João da Madeira & Sep 29, 2006 & \\
\hline CRPC Bombarral & Bombarral & Oct 31,2006 & \\
\hline CRC Lisboa & Lisboa & Oct 31,2006 & \\
\hline CRPC Odivelas & Odivelas & Oct 31,2006 & \\
\hline CRPC Vila Franca de Xira & Vila Franca de Xira & Oct 31,2006 & \\
\hline CRC Cascais & Cascais & Nov 30,2006 & \\
\hline
\end{tabular}




\begin{tabular}{|c|c|c|c|}
\hline One-Stop Shop & County & Openning Date & Closing Date \\
\hline CRPC Portimão & Portimão & Nov 30,2006 & \\
\hline CRPC Chaves & Chaves & Nov 30,2006 & \\
\hline CRPC V.N. de Cerveira & Vila Nova de Cerveira & Dec 4,2006 & \\
\hline CRCPC Celorico de Basto & Celorico de Basto & Mar 30, 2007 & \\
\hline CRCPC Grândola & Grândola & Mar 30, 2007 & \\
\hline CRPC Lamego & Lamego & Mar 30, 2007 & \\
\hline CRPC Vila do Conde & Vila do Conde & Mar 30, 2007 & \\
\hline CRPC Covilhã & Covilhã & Apr 30,2007 & \\
\hline CRCPC Estremoz & Estremoz & Apr 30,2007 & \\
\hline CRCPC Monção & Monção & Apr 30,2007 & \\
\hline CRPC V.N. Famalicão & Vila Nova de Famalicão & Apr 30,2007 & \\
\hline CRPC Águeda & Águeda & May 31,2007 & \\
\hline CRPC Elvas & Elvas & May 31,2007 & \\
\hline CRCPC Seia & Seia & May 31,2007 & \\
\hline CRPC Torres Vedras & Torres Vedras & May 31,2007 & \\
\hline CRCPC Alcácer do Sal & Alcácer do Sal & Jun 29, 2007 & \\
\hline CRPC Figueira da Foz & Figueira da Foz & Jun 29, 2007 & \\
\hline CRPC Santiago do Cacém & Santiago do Cacém & Jun 29,2007 & \\
\hline CRCPC V.R. Santo António & Vila Real de Santo António & Jun 29,2007 & \\
\hline Postos dos Registos & Lisboa & Jul 6, 2007 & \\
\hline CRPC Mirandela & Mirandela & Sep 27, 2007 & \\
\hline CRCPC Oliveira do Bairro & Oliveira do Bairro & Sep 28, 2007 & \\
\hline CRCPC Sertã & Sertã & Sep 28, 2007 & \\
\hline CRCPC Vila Nova de Foz Côa & Vila Nova de Foz Côa & Sep 28, 2007 & \\
\hline CRCPC Fornos de Algodres & Fornos de Algodres & Oct 31,2007 & \\
\hline CRPC Pombal & Pombal & Oct 31,2007 & \\
\hline CRPC Tomar & Tomar & Oct 31,2007 & \\
\hline $1^{\circ} \mathrm{CNCE}$ Porto & Porto & Oct 31,2007 & \\
\hline CRPC Horta & Horta & Nov 30,2007 & \\
\hline CRPC Abrantes & Abrantes & Nov 30,2007 & \\
\hline CRPC Caldas da Rainha & Caldas da Rainha & Nov 30,2007 & \\
\hline CRPC Lagos & Lagos & Nov 30,2007 & \\
\hline CRPC Montemor-O-Novo & Montemor-O-Novo & Nov 30,2007 & \\
\hline Loja do Cidadão Odivelas & Odivelas & Dec 17, 2007 & \\
\hline CRCPC Aljustrel & Aljustrel & Jan 31,2008 & \\
\hline CRCPC Fafe & Fafe & Jan 31,2008 & \\
\hline CRPC Valongo & Valongo & Jan 31,2008 & \\
\hline $1^{\text {a } C R C ~ L o u r e s ~}$ & Loures & Feb 29, 2008 & \\
\hline CRC Espinho & Espinho & Feb 29, 2008 & \\
\hline CRC Oliveira de Azeméis & Oliveira de Azeméis & Feb 29, 2008 & \\
\hline CRC Tondela & Tondela & Feb 29, 2008 & \\
\hline $1^{\text {a } C R C ~ A l m a d a ~}$ & Almada & Mar 31, 2008 & \\
\hline CRC Figueira de Castelo Rodrigo & Figueira de Castelo Rodrigo & Mar 31, 2008 & \\
\hline CRC Idanha-A-Nova & Idanha-A-Nova & Mar 31, 2008 & \\
\hline CRC Moimenta da Beira & Moimenta da Beira & Mar 31, 2008 & \\
\hline CRC Aljezur & Aljezur & Apr 30,2008 & \\
\hline CRC Almeida & Almeida & Apr 30, 2008 & \\
\hline $1^{\circ} \mathrm{CNCE}$ Castelo Branco & Castelo Branco & Apr 30,2008 & \\
\hline CRC Vila Verde & Vila Verde & Apr 30,2008 & \\
\hline CRC Alfândega da Fé & Alfândega da Fé & May 30, 2008 & \\
\hline CRC Macedo de Cavaleiros & Macedo de Cavaleiros & May 30,2008 & \\
\hline CRC Odemira & Odemira & May 30,2008 & \\
\hline CRC Ovar & Ovar & May 30,2008 & \\
\hline CRC Ílhavo & Ílhavo & Jun 30,2008 & \\
\hline CRC São João da Pesqueira & São João da Pesqueira & Jun 30,2008 & \\
\hline
\end{tabular}




\begin{tabular}{|c|c|c|c|}
\hline One-Stop Shop & County & Openning Date & Closing Date \\
\hline $1^{\mathrm{a}}$ CNCE. Guarda & Guarda & Jun 30,2008 & \\
\hline $1^{\mathrm{a}} \mathrm{CNCE}$ Matosinhos & Matosinhos & Jun 30,2008 & \\
\hline CRC Alcobaça & Alcobaça & Sep 30, 2008 & \\
\hline CRC Felgueiras & Felgueiras & Sep 30, 2008 & \\
\hline CRC Mora & Mora & Sep 30, 2008 & \\
\hline CRC Valença & Valença & Sep 30, 2008 & \\
\hline CRC Óbidos & Óbidos & Oct 31,2008 & \\
\hline CRC Ponte da Barca & Ponte da Barca & Oct 31,2008 & \\
\hline CRC Ponte de Lima & Ponte de Lima & Oct 31,2008 & \\
\hline CRC Trofa & Trofa & Oct 31,2008 & \\
\hline CRC Cantanhede & Cantanhede & Nov 28,2008 & \\
\hline CRC Montalegre & Montalegre & Nov 28,2008 & \\
\hline CRC Moura & Moura & Nov 28,2008 & \\
\hline CRC Ponte de Sôr & Ponte de Sôr & Nov 28,2008 & \\
\hline CRC Santo Tirso & Santo Tirso & Nov 28,2008 & \\
\hline CRP Serpa & Serpa & Feb 6, 2009 & \\
\hline CRP Alcanena & Alcanena & Feb 20, 2009 & \\
\hline CRP Caminha & Caminha & Feb 20, 2009 & \\
\hline CRP Ferreira do Zêzere & Ferreira do Zêzere & Feb 20, 2009 & \\
\hline CRP Marco de Canaveses & Marco de Canaveses & Mar 17, 2009 & \\
\hline CRP Mortágua & Mortágua & Mar 17, 2009 & \\
\hline CRP Murça & Murça & Mar 17, 2009 & \\
\hline CRP Borba & Borba & Mar 17, 2009 & \\
\hline CNCE de Viseu & Viseu & Apr 8, 2009 & \\
\hline CRP Ferreira do Alentejo & Ferreira do Alentejo & Apr 8, 2009 & \\
\hline CRP Pedrogâo Grande & Pedrogâo Grande & Apr 8, 2009 & \\
\hline CRP Valpaços & Valpaços & Apr 8, 2009 & \\
\hline CRP Penafiel & Penafiel & Apr 8, 2009 & \\
\hline CRP Murtosa & Murtosa & Apr 8, 2009 & \\
\hline CRP Arganil & Arganil & May 4, 2009 & \\
\hline CRP Mafra & Mafra & May 4,2009 & \\
\hline CRP Armamar & Armamar & May 4, 2009 & \\
\hline CRP Arouca & Arouca & May 4, 2009 & \\
\hline CRP Vila Flor & Vila Flor & May 4, 2009 & \\
\hline CRP Azambuja & Azambuja & May 29, 2009 & \\
\hline CRP Cadaval & Cadaval & May 29, 2009 & \\
\hline CRP Sobral de Monte Agraço & Sobral de Monte Agraço & May 29, 2009 & \\
\hline CRP Resende & Resende & May 29, 2009 & \\
\hline CRP Castanheira de Pêra & Castanheira de Pêra & Jun 18, 2009 & \\
\hline CRP Batalha & Batalha & Jun 25, 2009 & \\
\hline CRP Ourique & Ourique & Jun 25, 2009 & \\
\hline CRP Rio Maior & Rio Maior & Jun 25, 2009 & \\
\hline CRP Barcelos & Barcelos & Jul 9, 2009 & \\
\hline CRP Tavira & Tavira & Aug 31, 2009 & \\
\hline CRP Arruda dos Vinhos & Arruda dos Vinhos & Sep 7, 2009 & \\
\hline CRP Cartaxo & Cartaxo & Sep 7, 2009 & \\
\hline CRP Vimioso & Vimioso & Sep 7, 2009 & \\
\hline CRP Peniche & Peniche & Sep 7, 2009 & \\
\hline CRP Seixal & Seixal & Sep 7, 2009 & \\
\hline CRP Vouzela & Vouzela & Sep 7, 2009 & \\
\hline CRP Campo Maior & Campo Maior & Sep 7, 2009 & \\
\hline CRP Entroncamento & Entroncamento & Oct 2, 2009 & \\
\hline CRP Freixo de Espada á Cinta & Freixo de Espada á Cinta & Oct 2, 2009 & \\
\hline CRP Marinha Grande & Marinha Grande & Oct 2, 2009 & \\
\hline CRP Oliveira do Hospital & Oliveira do Hospital & Oct 2, 2009 & \\
\hline
\end{tabular}




\begin{tabular}{|c|c|c|c|}
\hline One-Stop Shop & County & Openning Date & Closing Date \\
\hline CRP Alenquer & Alenquer & Oct 27,2009 & \\
\hline CRP Lourinhã & Lourinhã & Oct 27,2009 & \\
\hline CRP Nazaré & Nazaré & Oct 27,2009 & \\
\hline SIR- Soluções Integradas de Registo & Lisboa & Oct 27,2009 & \\
\hline CRP Póvoa de Varzim & Póvoa de Varzim & Nov 20, 2009 & \\
\hline CRP Belmonte & Belmonte & Nov 20, 2009 & \\
\hline CRP Nelas & Nelas & Nov 20, 2009 & \\
\hline CRP Mangualde & Mangualde & Nov 20, 2009 & \\
\hline Espaço Registos do Areeiro & Lisboa & Dec 2, 2009 & \\
\hline
\end{tabular}

Note: CFE is Centro de Formalidades de Empresas; CRC is Conservatória do Registo Comercial; CRP is Conservatória do Registo Perdial; CRCPC is Conservatória do Registo Civil, Predial e Comercial; CRPC Conservatórias do Registo Predial e Comercial; CNCE is Cartório de Competência Especializada; RNPC is Registo Nacional de Pessoas Colectivas. 


\section{A.3 Data and Construction of Variables}

The data in this paper come from the matched employer- employee dataset (Quadros de Pessoal or SISED - Sistema de Informação de Salários, Emprego e Duração do Trabalho), which is a mandatory survey submitted annually in October by all firms with at least one employee. This database collects information on an average of 227,000 firms and two million individuals per year, covering virtually all employees and firms in the Portuguese private sector.

This database is generally available annually from 1982 onward, however we restrict our analysis to the period between 2000 and 2008. Data are unavailable for the year 2001.

The database contains three related sets of records: one at the firm level, other at the establishment level and the last one at the employee level. Employees, firms and establishments are cross referenced by a unique identifier. Each year, firms report their year of incorporation, location (concelho or county where the main offices are located), main industry, number of employees, number of establishments, initial capital, ownership structure and sales. At the establishment level, firms report the number of employees, location, and main industry. At the individual level, the database contains information on gender, age, date of hire, education, occupation, working hours, and October's earnings. However, the employee records include redundant data or data with frequent changes in gender and/or year of birth for individual employees. We consider these observations to be errors, corresponding to individuals whose identification number was not inserted or wrongly identified by the respondent. We drop individuals whose gender and year birth change in more than 70 percent of the total number of observations.

From the firm and employee databases, we construct the following variables:

Year of foundation is computed as the minimum of the year of creation reported in the database, the year that the firm first appeared in the database and the year of hire of the first employee.

Month of foundation is computed as the month of hire of the first employee when the year of hire coincides with the year of foundation.

Survival $S$ is an indicator variable equaling one for start-ups that survived their first two years. Firms are classified as non-survivors if they do not appear in the database in following years. In order to compute the survival rate, we exclude the last two years of the database (2007 and 2008). Firms can fail to appear in the database, even if they remain going concerns. For instance, a firm might fail to send the survey in by the due date for two consecutive years. Using data from previous years, however, we estimate that the probability of such non-response occurring in two consecutive years is less than one percent.

Size Size is the start-up's initial number of employees. This measure is computed as the total number of individuals in the employee records in the foundation year.

Gender Gender is a dummy variable equaling one for men and zero for women.

Age is coded in years in the database. We define four categorical variables: Age 20-29 is coded one for individuals with age between 20 and 29; Age30 - 39 is coded one for individuals 
with age between 30 and 39; Age40 - 49 is coded one for individuals with age between 40 and 49; Age50 - 60 is coded one for individuals with age between 50 and 60 .

Education is measured with four categorical variables: higheducation is a dummy variable equaling one for founders with bachelors, masters or doctoral degrees; mediumeducation is a dummy variable equaling one for individuals reporting a high school diploma or vocational school degree; loweducation is a dummy variable equaling one for individuals that attended junior high school; and veryloweducation is a dummy variable equaling one for individuals who never attended or completed the elementary school.

Industry Experience Ind is coded one for entrepreneurs with experience in the same industry (four digit level) as that of the firms they found. Industry classification changed in 1994 and 2007, and there is no unequivocal relation between the old and new codes. To mitigate errors, we use all unique relations to translate old to new codes and, vice versa. Then, we compute the variable industry experience for the new and old codes and aggregate both results. Alternatively, we also use an algorithm, which is based on how the majority of firms changed industry codes from 1994 to 1995 to translate old into new codes. For 2007, this problem is mitigated because the database provides information on the new and old industry classification.

From the one-stop shop opening dates, we construct the following variables:

One-Stop Shop ENH (month) is a dummy variable equaling one for the month and county in which the one-stop shop opened, and for all the following months. Counties whose shops open in the first 15 days of a month will see the effects of the program in that month. If the shop opened in the last 15 days of a month, the effect of deregulation will begin in the following month.

One-Stop Shop ENH (year) is a dummy variable equaling one for the year and county in which the one-stop shop opened, and for all the following years. Counties whose shops open in the first six months of a year will see the effects of the program on that year. If the shop opened in the last six months of a year, the effect of deregulation will begin in the following year. 